\title{
Correspondence
}

To the Editors

\section{COVID-19, paediatric dental caries and severity of disease: a complex interrelationship}

Sri Lanka Journal of Child Health, 2021: 50(3): 563-564

DOI: http://doi.org/10.4038/sljch.v50i3.9751

(Key words: Covid-19, dental caries, children, severity of disease)

Dear Editors,

An important public health problem among the paediatric population worldwide is dental caries. Poor dental hygiene is the main cause of dental caries $^{1}$. However, other factors may also affect the dental health of children. During the COVID-19 pandemic, the management of dental caries among children became more difficult than usual ${ }^{2}$. The interrelationship between COVID-19 and dental caries in children is an interesting issue. Firstly, although COVID-19 can have many atypical clinical presentations, including oral presentation, dental problems are hardly ever mentioned ${ }^{3}$.

There is no evidence that SARS CoV2 causes problems to sort out dental issues. Nevertheless, COVID-19 can cause difficulty in dental care assessment and there was a report that the fear of SARS-CoV-2 was associated with poor oral healthrelated quality of life during the COVID-19 pandemic ${ }^{4}$. In China, during the lockdown, a high percentage of children reported the problem of dental caries ${ }^{5}$. There is no doubt that there is an indirect effect of COVID-19 on dental caries. There are very few reports for a direct relationship between dental caries and COVID-19. Dziesdzic A, et al recently reported that tooth loss in COVID-19 might be a consequence of soft tissue inflammation due to COVID-196. Additionally, the relationship between COVID-19 and the dental damage stage determined by radiological examination was recently proposed ${ }^{6}$. The severity and prognosis of the disease was found to be related to dental problems ${ }^{6}$. For a possible explanation, there is a recent report showing that periodontopathic bacteria in a COVID-19 patient with underlying periodontitis and caries might have led to aspiration and lung problems ${ }^{7}$. This may be superimposed on the lung problem due to SARS CoV-2 and result in a more severe illness.

Finally, suboptimal vitamin D level in children is reported to increase the risk of caries ${ }^{8}$. It is possible that there is a concurrent problem between vitamin $\mathrm{D}$ deficiency and caries in children. Vitamin D deficiency is also reported to increase the risk of COVID-199. There might be a possible interrelationship between vitamin D deficiency, dental caries and COVID-19.
References

1. Alazmah A. Early childhood caries: Journal of Contemporary Dental Practice 2017; 18(8): 732-7.

https://doi.org/10.5005/jp-journals-100242116

PMid: 28816199

2. Al-Halabi M, Salami A, Alnuaimi E, Kowash M, Hussein I. Assessment of paediatric dental guidelines and caries management alternatives in the post COVID-19 period. A critical review and clinical recommendations. European Archives of Paediatric Dentistry 2020; 21(5): 543-56. https://doi.org/10.1007/s40368-020005475

PMid: 32557183 PMCid: PMC7298449

3. Tin SS, Wiwanitkit V. Atypical presentations of COVID-19. Journal of Health Science and Medical Research 2020; 38(2): 153-8.

https://doi.org/10.31584/jhsmr.2020733

4. Samuel SR, Kuduruthullah S, Khair AMB, Shayeb MA, Elkaseh A, Varma SR. Dental pain, parental SARS-CoV-2 fear and distress on quality of life of 2 to 6 year-old children during COVID-19. International Journal of Paediatric Dentistry 21 November 2020.

https://doi.org/10.1111/ipd.12757

PMid: 33220088 PMCid: PMC7753551

5. Liu C, Zhang S, Zhang C, Tai B, Jiang H, $\mathrm{Du}$ M. The impact of coronavirus lockdown on oral healthcare and its associated issues of pre-schoolers in China: an online cross-sectional survey. $B M C$ Oral Health 2021; 21(1): 54. https://doi.org/10.1186/s12903-021014109

PMid: 33549091 PMCid: PMC7865116 
6. Dziedzicc A, Wojtyczka R. The impact of coronavirus infectious disease 19 (COVID19) on oral health. Oral Diseases 18 April 2020. https://doi.org/10.1111/odi.13359 PMid: 32304276 PMCid: PMC7264805

7. Takahashi Y, Watanabe N, Kamio N, Yokoe S, Suzuki R, Sato S, et al. Expression of the SARS-CoV-2 receptor ACE2 and proinflammatory cytokines induced by the periodontopathic bacterium Fusobacterium nucleatum in human respiratory epithelial cells. International Journal of Molecular Sciences 2021; 22(3): 1352.

https://doi.org/10.3390/ijms22031352

PMid: 33572938 PMCid: PMC7866373

8. Almoudi MM, Hussein AS, Abu Hassan MI, Schroth RJ. Dental caries and vitamin
D status in children in Asia. Pediatric International 2019; 61(4): 327-38. https://doi.org/10.1111/ped.13801 PMid: 30740822

9. Mohan M, Cherian JJ, Sharma A. Exploring links between vitamin D deficiency and COVID-19. PLoS Pathogens 2020; 16(9): e1008874. https://doi.org/10.1371/journal.ppat.10088 74

PMid: 32946517 PMCid: PMC7500624

\section{*Somsri Wiwanitkit ${ }^{1}$, Viroj Wiwanitkit ${ }^{2}$}

${ }^{1}$ Private Academic Consultant, Bangkok Thailand

${ }^{2}$ Honorary Professor, Dr. DY Patil University, Pune, India

*Correspondence: somsriwiwan@hotmail.com

https://orcid.org/ 0000-0002-9486-9473 